\title{
INFLUENCING FACTORS ON PERFORMANCE OF SOCIAL BEHAVIOR SETTINGS AT PARKS AND GREEN SPACES OF TABRIZ
}

\author{
Ali Majnouni TOUTAKHANE \\ University of Bonab, Iran
}

\begin{abstract}
Parks and green spaces are significant areas that are necessary to reduce citizens' mental and moral pressures more than ever. So, as for the importance of parks and urban green spaces, consideration of influencing factors on performance of these areas as citizen's social behavior setting is basically significant. This research seeks to answer the question of how citizens' behaviors are distinctly the same in terms of gender, age and social and economic characteristics in urban parks. The population of this research is represented by those who go to the parks and green spaces of Tabriz metropolis. The Cochran's formula was used to select a sample of 400 subjects who were specified by a simple random method. The reliability of the questionnaire was calculated at 0.902 using the Cronbach's alpha formula while the research data was analyzed via the descriptive-inferential approach. The implementation of factor analysis model reduced the 62 variables of citizens' social behavior to 23 variables and 4 factors. In considering the effects on citizen's behavior in parks, these factors in order of preference are: socialpsychological, physical-structural, economic and environmental. These four factors can explain $85.272 \%$ of the citizen's social behavior. The stepwise regression test results showed that all the analyzed variables, referring to the performance of citizen's social behavioral setting in parks and urban green spaces, are positively and meaningfully correlated. The independent t-test results showed that the urban park performances as behavior setting register significant differences between men and women. In this sense, the conclusions of the paper highlight the need to consider the complex needs of the residents in the designing and execution process of urban parks and green spaces.
\end{abstract}

Key Words: performance, social behavior setting, park, green space, gender

\section{Introduction}

The need to establish social relations in urban settings contributes to the engagement with social and city-made spaces with respect to cognitive interactions, behavior and emotional formats, and one of its results is the belonging to location (Dobbs et al. 2014, Filipan et al. 2017). The successful design of green spaces and urban parks is effective in increasing the citizen satisfaction together with the quality of the living environment (Xu et al. 2017, Ngesan et al. 2018). In the absence of the required standards, patterns and citizens' behavior setting will be disrupted (Douglas et al. 2017). Urban spaces, especially residential districts, have evolved during the last half-century due to globalization; they have undergone dramatic changes (Middel et al. 2015, Shin et al. 2017). Urban development has happened in risky and vulnerable conditions for the developing communities and it has disrupted the people's connection to the life environment (Chiesura 2004, Nordh et al. 2011, Du et al. 2013). Citizens are exposed to the polluted and industrialized space of cities, and this situation has caused citizens' stress (Jennings et al. 2016). These spaces are places and settings for recreation and rest for the benefit of the citizens, in order for them to escape from the problems of urban life (LoukaitouSideris 1995, Stefansdottir 2018).

We may recognize the importance of urban parks, especially in metropolitan areas, when we 
conclude that urban citizens are functionally separated from the natural environment. Such separation has made them both morally and mentally sick, conducting to increased crime and villainy in the urban environment, in such a way that we may understand better the formation of the life machine (Thompson 2002, Potestio et al. 2009). In other words, parks and urban green spaces have constructive socioeconomic and ecological roles (Ignatieva et al. 2011). These spaces are advantageous for the treatment of mental illnesses, they represent a desirable environment to nurture children, and for social integration, to maintain comfort and to generally contribute to improving the quality of urban life (Galea et al. 2005, Colding and Barthel 2013).

Additionally, urban parks are settings for the residents' spiritual, mental and behavioral recovery (Balram and Dragićević 2005, You 2016). Therefore, the citizens' needs and requirements are basically important and they must be studied in the designing process of parks and green spaces (Borer 2006, Coombes et al. 2010, Kong et al. 2010). In other words, the social, cultural, psychological, economic, and natural dimensions of urban areas, especially within large metropolitan centers, must be considered in constructing parks and green spaces as the most effective urban setting for the citizens (Chiesura 2004). Accordingly, parks and urban green spaces have a mutual influence and effect while people impact the environment through their behavior due to cultural, social, economic, and personal dimensions; people change and organize the environment to satisfy their physiologic and social needs (Zube 1995, Saldivar-Tanaka and Krasny 2004, Harnik 2006).

On the reciprocal relationship between the environment and people, Barker (1968), co-founder of the theory of ecological psychology, observes that when we are in different behavioral settings we undertake specific social roles then we match our future behavior; meanwhile, we try to organize the environment to be compatible with our behavioral needs (Blanchard 2004). Referring to the human behavior consistent with the environmental conditions, it was the first time that Barker (1968) used the term behavioral setting in developmental psychology when analyzing the social environment in the issue of children's physical psychology; then, other scientists and theoreticians in different disciplines, such as architects, urban designers, sociologists, criminologists, lawyers and so on, focused on this research problem and developed it (Baranowski et al. 2002, Malheiros and Vala 2004, Bresnahan et al. 2007, Noar et al. 2008, DiClemente et al. 2013, Toutakhane and Mofareh 2016). According to Barker (1968), for public spaces such as parks, green spaces and children's playgrounds, there are some constructive elements of behavioral setting for persistent activities in a place, and the pattern of individual behavior correlates with the structure of the place in a third-dimension arrangement of place-behavior, so that social behavior represents the outcome of symbiosis between the first and the second element. The highlight is that physical and behavioral dimensions of behavioral settings have a specific relationship (Barker 1968, Cosco et al. 2010). Moreover, Pearson (2012) and Bertram and Rehdanz (2015) observed that the behavioral setting is a small social unit formed by the sustainable incorporation of an activity and a place so that to meet the essential performances of the behavioral environment (Sanchez et al. 2017).

Also on the dimensions of the social behavioral setting in public environments, there is a relationship between the utilization of these spaces, the sense of ownership and the fixation to the space which is created through visual and mental connection (Wendel et al. 2012, Honold et al. 2016). In general, the behavioral setting is a physical space with practical and organizational objectives. The human behaviors in a behavioral setting are dependent upon the physical dimensions of the environment but also upon the collective behavior (Cosco et al. 2010, Guéguen and Stefan 2016). Tappert et al. (2018) observed that isolationism and reduced social interactions are the most important issues that threaten urban citizens' social life, therefore, people need these spaces to strengthen social interactions while complying with the social needs of the urban residents is an undeniable principle for cities.

In this regard, urban parks are both developed for recreation and for eliminating the fatigue of 
citizens. Furthermore, urban parks are directly related to the usage pattern and type of users' behavior in a space; they are both places for social interactions and areas where the citizens' organize their behavioral patterns (Carrus et al. 2015, Whitburn et al. 2018). On the effect of parks on the citizens' behavioral patterns, in an investigation, Liu (2012) demonstrated that citizen's behavioral patterns, including personal, social, space, and environmental behaviors, are influenced by their presence at park. Also, Balram and Dragićević (2005) concluded that citizens simultaneously play two vital roles within parks, as they respond to received signs and messages from the environment and they send additional signs and messages to the other people who are in such spaces as social elements and as main formation components of the behavioral environment (Barthel et al. 2015).

Referring to the lack of similar research on the influencing factors of the performance of parks and green spaces in relation to citizens' social behavioral settings in the Tabriz metropolis, the general objective of this research is to answer the following questions: which are the influencing factors on the performance of behavioral settings in urban parks and green spaces? How much is gender impacting the behavior setting variance of performance in urban parks and green spaces?

\section{Methodology}

\section{Study area}

Tabriz metropolis is located in the north-west of Iran, more exactly in the west of eastAzarbaijan province and at the end of the east-south plain. The city's altitude above sea level is $1348 \mathrm{~m}$. Its weather is dry steppe with warm and dry summers and cold winters. Based on the last census report, its population is of 1741655 people and it is the fifth most populous Iranian city. More than $96.5 \%$ of citizens are Azari speakers. Also, the main religion of the people of this city is Shia-Islam (98.64\%). Tabriz metropolis is the administrative, communicational, political, cultural and military center of west-north of Iran and there are some several national universities located there. Tabriz is also the largest economic hub of west-north and Azari regions. Widespread heavy industry is centralized in Tabriz. Because Tabriz is developed in industry, many people from other cities migrate to Tabriz to find job opportunities.

There are 138 parks of different sizes located in Tabriz. Among them, 46 are neighborhood parks, 53 are district parks, 27 represent area parks, 7 zone parks, and 5 others are urban parks. In 2011, there was an average of $14.8 \mathrm{~m}^{2}$ of park per capita in Tabriz. Across Iran, the mean is of $9 \mathrm{~m}^{2}$ per capita. But, according to the global standard of 20 to $25 \mathrm{~m}^{2} /$ capita, the situation in Tabriz is not better enough (Toutakhane and Mofareh 2016). And, it is estimated that an average of 180000 citizens and passengers of Tabriz metropolis spend around 3 hours of their daily time in different parks of various scales.

\section{Social assessment of parks and green spaces}

This research is both descriptive and inferential in its approach, using correlation methodologies. In fact, the main objective of this research is investigating the presence or absence of correlation between the elements of Tabriz metropolis parks in regulating the citizens' social behavior, together with recognizing the importance level of each variable and with surveying the effects of these elements according to population gender. Data is drawn from the surveyed visitors of parks and green areas in Tabriz. The surveys were conducted in Elgoli, Mashrooteh, Azerbaijan, Baghmisheh, Einali, Eram, Khaghani, Shams Tabrizi, Shamim Paidary, and Valiasr parks. The number of people that visited the parks mentioned above within a month is: $N=214535$. Given the large number of parks and green spaces in Tabriz (a total of 617 parks and green spaces of small and large scales) and the impossibility to distribute the questionnaire in all of these places, we have chosen these 10 parks and green 
spaces as random sample. The criteria for the selection of the case studies was simple random until the chance to be chosen was equal and all of the parks in Tabriz of small and large scales were included (Fig. 1, Fig. 2).

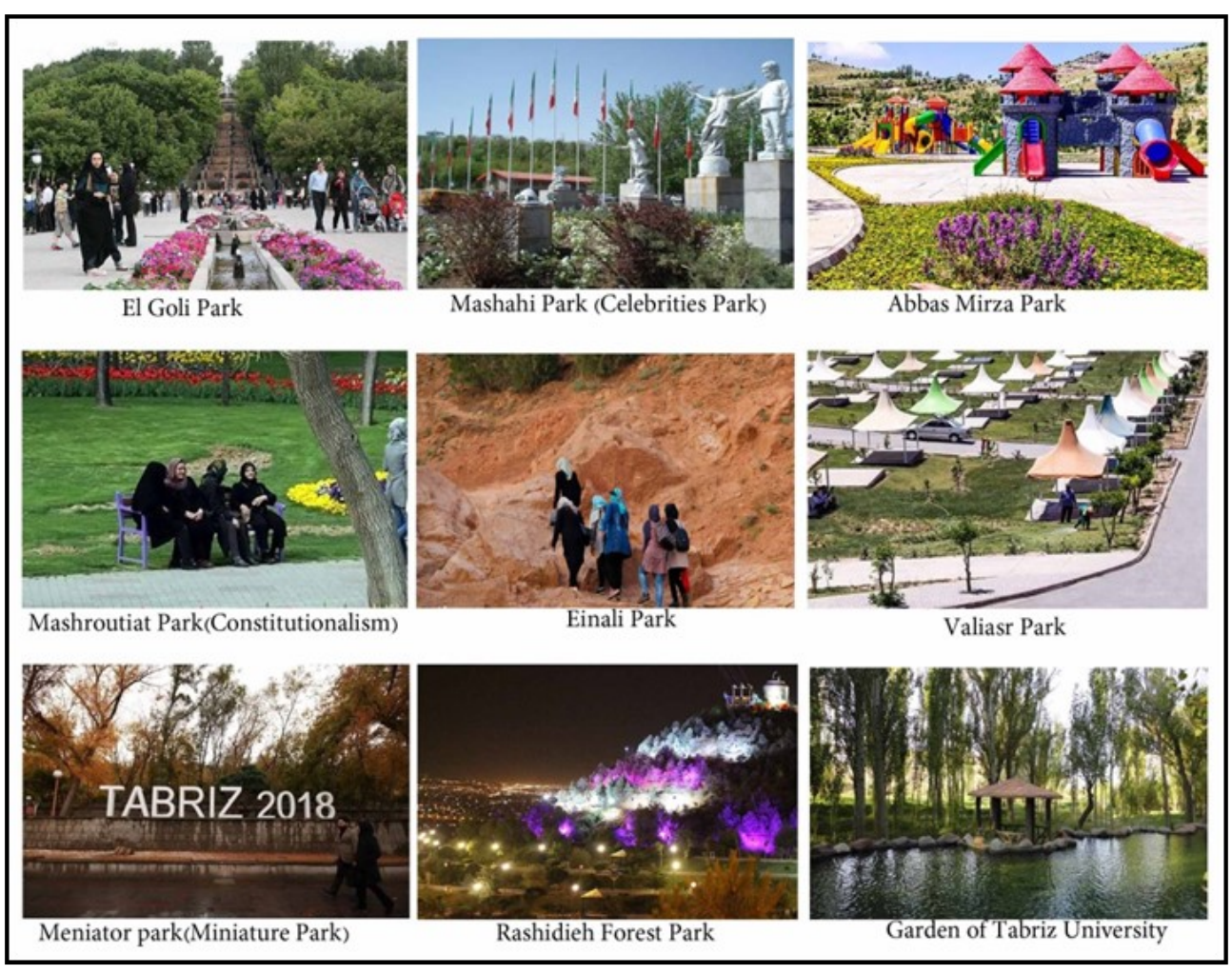

Fig. 1 - Parks in Tabriz Source: Author (2018)

Also, the 400 subjects of the study survey were selected based on the Cochran formula via the simple random sampling method (Bartlett et al. 2001). Survey results were classified in two types of documentary (secondary data) and survey (primary data). The questionnaire and the oral interview were used for survey. The total number of variables that were used in this research was 64 variables. A five-choice (Likert 5 Option) questionnaire was used to measure the variables. In the scoring stage, because a group of questions were designed in a negative aspect by the SPSS software, we coded questions again. So the questions' answers are: $5=$ completely agree, $4=$ agree, $3=$ no idea, $2=$ disagree and $1=$ completely disagree. Variables used in this study followed from the variables used in previous research (Table 1).

A panel of experts supported the face validity of the questionnaire. A pilot study was conducted in the same area with 50 questionnaires, then the reliability of the research questionnaire was obtained, and it was 0.902 by using the specific Cronbach's alpha formula (Helms et al. 2006) and the SPSS software. Finally, according to the theoretical foundations of the research, the data were collected through the questionnaire, for studying the influencing factors on citizens' satisfaction of performances of parks and urban green spaces as behavioral settings, and we 
Independent variables used in this research

$\operatorname{Sex}\left(A_{1}\right), \operatorname{Age}\left(A_{2}\right)$, Education $\left(A_{3}\right)$, Family $\left(A_{4}\right)$, Trust in others $\left(A_{5}\right)$, Sense of place $\left(A_{6}\right)$, Social interaction(A7),Feeling of security $\left(A_{8}\right)$, Motivation $\left(A_{9}\right)$,Sense of need $\left(A_{10}\right)$ Intimacy $\left(A_{11}\right)$,Compatibility $\left(A_{12}\right)$, Sense of jolly and happiness $\left(A_{13}\right)$, Satisfaction of the park $\left(A_{14}\right)$, Conflicts resolution $\left(A_{15}\right)$, Addicted peoples' footwork $\left(A_{16}\right)$, Presence of the police agents $\left(A_{17}\right)$, Rape $\left(A_{18}\right)$, Memories retrieve $\left(A_{19}\right)$, Satisfaction of management and behaviors of park personnel $\left(A_{20}\right)$, Saving $\left(A_{21}\right)$, Income, The diversity of sources of income $\left(A_{22}\right)$, Consent of adequacy $\left(A_{23}\right)$, Revenue and expenses $\left(A_{24}\right)$, Job satisfaction $\left(A_{25}\right)$, Costs of entrance utilization of park facilities $\left(A_{26}\right)$, Entrance cost to the park $\left(A_{27}\right)$, Finding a suitable place in the park, Finding a playground for children $\left(A_{28}\right)$, Diversity $\left(A_{29}\right)$, Diversity of access points to the park $\left(\mathrm{A}_{30}\right)$, Satisfaction of park facilities $\left(A_{31}\right)$, Satisfaction of recreation facilities in the park $\left(A_{32}\right)$, Access to parking $\left(A_{33}\right)$, Quality of streets in the park $\left(A_{35}\right)$, Access to parking (A $\left.{ }_{36}\right)$, Removal of blind spots in the park $\left(A_{37}\right)$, Comprehensiveness of Park services $\left(A_{38}\right)$, Arrangement of furniture $\left(A_{39}\right)$, Proper view $\left(A_{40}\right)$, Visual quality of vegetation $\left(A_{42}\right)$, Appearance quality of roads in the park $\left(\mathrm{A}_{43}\right)$, Proper location of canopies $\left(\mathrm{A}_{44}\right)$, Signs and signboards $\left(\mathrm{A}_{45}\right)$, Proper coloring $\left(A_{46}\right)$, Facades of shops, Entertainment centers and trade centers $\left(A_{47}\right)$, Landscape of fountains and waterfalls $\left(A_{48}\right)$, Views of lighting $\left(A_{49}\right)$, Reflection of sunlight by tools in the park $\left(A_{50}\right)$, Environment pollution $\left(A_{51}\right)$, Environmental health $\left(A_{52}\right)$, Wind directions $\left(A_{53}\right)$, Rain(A54), Freezing in cold seasons $\left(A_{55}\right)$, Vernacular materials $\left(A_{56}\right)$, Sewage disposal $\left(A_{57}\right)$, Climate comfort $\left(A_{58}\right)$, Plant diversity $\left(A_{59}\right)$, The quality of drinking water $\left(A_{60}\right)$, The quality of lawn and flower planting $\left(A_{61}\right)$, Noise pollution $\left(A_{62}\right)$

(Potestio et al. 2009, Coombes et al. 2010, Thompson et al. 2012, Wendel et al. 2012, Lachowycz and Jones 2013, Wolch et al. 2014) (De Sousa 2003, Barbosa et al. 2007, Coutts et al. 2010, Bertram and Rehdanz 2015)

(Jokimäki 1999, Li and Wang 2004, Caspersen et al. 2006, Sandström et al. 2006, Chen et al. 2009, Kong et al. 2010, Rutt and Gulsrud 2016) (Heynen et al. 2006, Sister et al. 2010, Veitch et al. 2012, Barthel et al. 2015, Rupprecht et al. 2015)

Source: Author, based on various sources (2018)

analyzed the variables by computing the factor analysis test and the stepwise multivariate regression. Therefore, the factor analysis test was used to summarize data and information, while the stepwise linear regression was used to anticipate the behavior of the dependent variables.

In this study, we used several statistical methods to analyze the data of the questionnaire as follows: 1. The factor analysis model was used to categorize the variables of the research as well as to identify the factors that had the most impact; 2 . A multivariate regression test has been used to prove or reject the research hypotheses; 3 . The T test was used to examine the differences between the two groups of the studied population (men and women) about the type of behavior in the park environment.

The objective of the factor analysis is to reduce the numerous variables to components for the improved analysis (Tobias and Carlson 1969, McDonald 2014). In general, the factor analysis includes the following steps: formation of data matrix, calculation of correlation matrix, extraction of factors, factors time, naming the factors (Williams et al. 2010). Mostly KMO or Kaiser-Meyer-Olkin (Williams et al. 2010) was used for the statistics calculation and its value is fluctuating between 0 and 1 . It has been used to eliminate the differences of concerning indices. Whenever $\mathrm{KMO}$ is lower than 0.5 , the data are not suitable for the factor analysis. If the value is between 0.5 and 0.69 , the data are average, but when the index is greater than 7 , the correlations between the data are suitable for the factor analysis (Williams et al. 2010). 


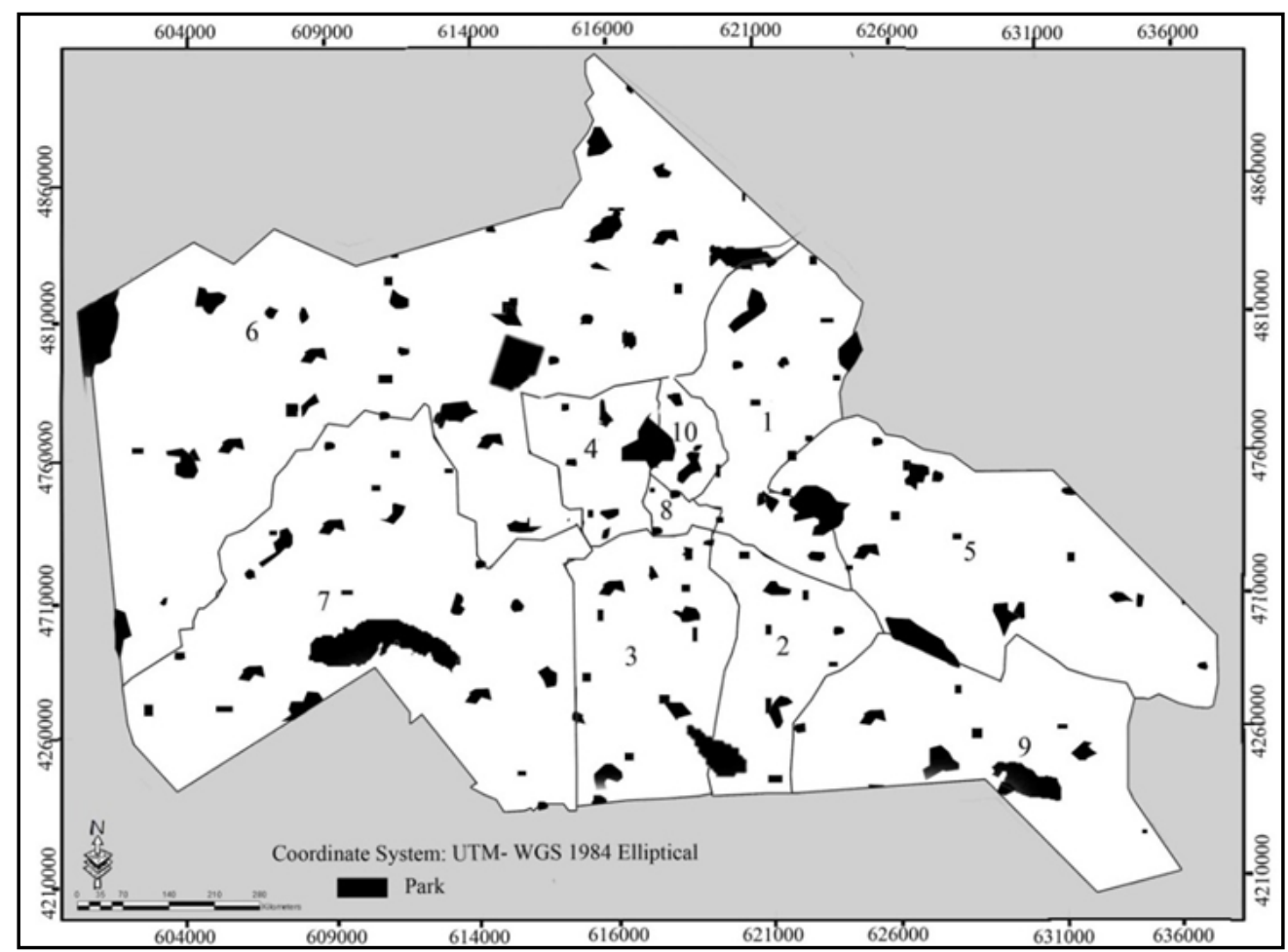

Fig. 2 - Geographical location of parks and green spaces in the Tabriz metropolis Source: Author (2018)

The statistical results were obtained by enforcing the factor analysis model based on the studied indices which showed that the KMO standard is equal to 0.837 and it supports the factor analysis model and it expresses its suitability for research (Table 2).

Table 2

The result of Kaiser-Meyer-Olkin (KMO) and Bartlett's Test

\begin{tabular}{|l|l|l|}
\hline \multicolumn{2}{|l|}{ Kaiser-Meyer-Olkin Measure of Sampling Adequacy } & 0.837 \\
\hline \multirow{3}{*}{ Bartlett's Test of Sphericity } & Approx. Chi-Square & 3425.210 \\
\cline { 2 - 3 } & df & 400 \\
\cline { 2 - 3 } & Sig & 0.000 \\
\hline
\end{tabular}

Source: Author's calculation (2018)

Finally, the standards were classified through the factor analysis test and the multivariate regression test. The following hypotheses were tested: 
- It seems that there is a correlation between the social, psychological, structural, environmental and economic factors with the type of citizenship behavior in parks and green spaces.

- It seems that there is a difference between gender and the behavior type of the citizens in urban parks and green spaces.

\section{Results}

The surveying results on the characteristics of the 10 parks investigated in this study are presented in Table 3.

Table 3

Characteristics of the 10 parks studied in Tabriz

\begin{tabular}{|c|c|c|c|c|}
\hline Park & $\begin{array}{l}\text { Area Size } \\
\text { (Meters) }\end{array}$ & $\begin{array}{l}\text { Design } \\
\text { type }\end{array}$ & Elements in the park & Type of Use \\
\hline Elgoli & 54675 & Artificial & $\begin{array}{l}\text { Tree, flowers and bushes, playground, } \\
\text { recreational facilities, shopping malls, } 5 \\
\text { star hotel, historical spaces and museums }\end{array}$ & $\begin{array}{l}\text { Recreation, } \\
\text { exercise, } \\
\text { tourists }\end{array}$ \\
\hline Azerbaijan & 32254 & Artificial & $\begin{array}{l}\text { Tree, flowers and bushes, children's play } \\
\text { space, family rest, morning exercise, 3D } \\
\text { cinema, multi-purpose hall of crisis man- } \\
\text { agement }\end{array}$ & $\begin{array}{l}\text { Recreation, } \\
\text { morning } \\
\text { exercise, } \\
\text { tourists }\end{array}$ \\
\hline Baghmisheh & 42568 & Artificial & $\begin{array}{l}\text { Green area, restaurant and coffee shop, } \\
\text { shopping complex, chapel, toilet, water- } \\
\text { front }\end{array}$ & $\begin{array}{l}\text { Recreation, } \\
\text { morning exercise, } \\
\text { tourists, shopping }\end{array}$ \\
\hline Einali & 45696 & $\begin{array}{l}\text { Artificial } \\
\text { \& Natural }\end{array}$ & $\begin{array}{l}\text { Mountaineering, nature riding, sleigh rides, } \\
\text { cable car }\end{array}$ & $\begin{array}{l}\text { Recreation, } \\
\text { exercise, tourists, } \\
\text { shopping }\end{array}$ \\
\hline Eram & 25478 & Artificial & $\begin{array}{l}\text { Hotel, campgrounds, car parking, day } \\
\text { market, vegetation, coffee shop, theater \& } \\
\text { cinema, waterfront }\end{array}$ & $\begin{array}{l}\text { Recreation, } \\
\text { exercise, tourists, } \\
\text { shopping }\end{array}$ \\
\hline Khaghani & 32102 & Artificial & $\begin{array}{l}\text { Green area, restaurant and coffee shop, } \\
\text { shopping complex, chapel, toilet }\end{array}$ & $\begin{array}{l}\text { Recreation, } \\
\text { exercise, tourists }\end{array}$ \\
\hline $\begin{array}{l}\text { Shams Ta- } \\
\text { brizi }\end{array}$ & 33521 & Artificial & $\begin{array}{l}\text { Green area, waterfront restaurant and } \\
\text { coffee shop, shopping complex, chapel, } \\
\text { toilet, multi-purpose hall of crisis manage- } \\
\text { ment }\end{array}$ & $\begin{array}{l}\text { Recreation, } \\
\text { exercise, tourists, } \\
\text { shopping }\end{array}$ \\
\hline $\begin{array}{l}\text { Shamim } \\
\text { Paidary }\end{array}$ & 45202 & Artificial & $\begin{array}{l}\text { Statue of the celebrities, tree, flowers and } \\
\text { bushes, playground, recreational facilities, }\end{array}$ & $\begin{array}{l}\text { Recreation, } \\
\text { exercise, tourists }\end{array}$ \\
\hline Valiasr & 39620 & Artificial & $\begin{array}{l}\text { Carouse, bird garden, exhibition, shop- } \\
\text { ping centers, children's playgrounds, well- } \\
\text { ness equipment, vegetation, flower show, } \\
\text { coffee shop }\end{array}$ & $\begin{array}{l}\text { Recreation, } \\
\text { exercise, tourists }\end{array}$ \\
\hline Mashrooteh & 17425 & Artificial & $\begin{array}{l}\text { Exhibits, shopping malls, libraries, chil- } \\
\text { dren's play equipment, fitness equipment, } \\
\text { vegetation, flower show, coffee shop, bike } \\
\text { rental }\end{array}$ & $\begin{array}{l}\text { Recreation, } \\
\text { exercise }\end{array}$ \\
\hline
\end{tabular}

Based on the survey findings, $53 \%$ of the respondents were men and $47 \%$ of them were women. In terms of respondents' age distribution, the most frequency rate was of $41.50 \%$ for the 30 to 40 years old people. $25.50 \%, 18.50 \%$ and $12.75 \%$ of the respondents had the bachelor's degree, diploma and the guidance school degree, respectively, and the park frequency rate was of $24.50 \%, 18.50 \%$, and $12.75 \%$, respectively. Also, the number of the weekly visits to the park -3 times per week - had the highest frequency distribution rate and it was of $49.50 \%$. The results about the traveled distance for getting to the park is represented by the average traveled distance according to the park type, and it is of $448 \mathrm{~m}$ for district parks, $985 \mathrm{~m}$ for neighborhood parks and $1.56 \mathrm{~km}$ for zone parks. In addition, according to the results, $34.33 \%$ of people use cars, $17.25 \%$ use bicycles and $48.42 \%$ walk the distance from 
home to get to the park.

Finally, in conjunction with the visit motivation to the park and urban green spaces, the highest frequency distribution rate was of $28 \%$, followed by $21.75 \%$ and $17.50 \%$, for refreshment, children's play and contact with the green space, respectively.

As mentioned, at the first step of the factor analysis model implementation, 62 variables were identified in relation to the performance of behavioral settings at parks and metropolis green spaces. The obtained calculation results are shown in Table 4 while some variables were omitted from the cycle of the model.

Eigenvalues and variance of the dependent variable

Table 4

\begin{tabular}{|l|c|c|c|c|}
\hline \multicolumn{1}{|c|}{ Model } & Total & Value (r) & Variance & $\%$ Variance \\
\hline $\mathrm{A}_{10}$ & 4.554 & 0.856 & 0.711 & 7.54 \\
\hline $\mathrm{A}_{16}$ & 4.520 & 0.842 & 0.768 & 7.362 \\
\hline $\mathrm{A}_{6}$ & 4.463 & 0.730 & 0.846 & 7.399 \\
\hline $\mathrm{B}_{6}$ & 3.155 & 0.743 & 0.890 & 6.109 \\
\hline $\mathrm{B}_{7}$ & 3.321 & 0.699 & 0.872 & 6.102 \\
\hline $\mathrm{A}_{18}$ & 3.222 & 0.687 & 0.870 & 5.778 \\
\hline $\mathrm{A}_{13}$ & 3.144 & 0.665 & 0.726 & 5.706 \\
\hline $\mathrm{A}_{14}$ & 2.443 & 0.644 & 0.917 & 5.693 \\
\hline $\mathrm{C}_{1}$ & 2.524 & 0.634 & 0.905 & 4.459 \\
\hline $\mathrm{C}_{3}$ & 2.365 & 0.628 & 0.871 & 4.243 \\
\hline $\mathrm{C}_{5}$ & 2.249 & 0.619 & 0.884 & 3.240 \\
\hline $\mathrm{C}_{10}$ & 2.201 & 0.617 & 0.804 & 2.707 \\
\hline $\mathrm{C}_{7}$ & 1.952 & 0.612 & 0.953 & 2.685 \\
\hline $\mathrm{C}_{14}$ & 1.754 & 0.581 & 0.954 & 2.543 \\
\hline $\mathrm{C}_{18}$ & 1.621 & 0.578 & 0.915 & 2.372 \\
\hline $\mathrm{C}_{6}$ & 1.428 & 0.575 & 0.865 & 2.235 \\
\hline $\mathrm{A}_{1}$ & 1.360 & 0.556 & 0.687 & 2.188 \\
\hline $\mathrm{A}_{2}$ & 1.275 & 0.549 & 0.986 & 2.175 \\
\hline $\mathrm{A}_{3}$ & 1.189 & 0.539 & 0.745 & 2.171 \\
\hline $\mathrm{D}_{13}$ & 1.124 & 0.533 & 0.675 & 2.164 \\
\hline $\mathrm{D}_{11}$ & 1.109 & 0.527 & 0.963 & 2.017 \\
\hline $\mathrm{D}_{12}$ & 1.085 & 0.525 & 0.753 & 2.010 \\
\hline $\mathrm{D}_{8}$ & 1.052 & 0.520 & 0.761 & 2.006 \\
\hline$S 0 u r e ; A u s$ & & \\
\hline
\end{tabular}

Source: Author's calculation (2018)

Based on the obtained results, among the 23 entered variables to the men's group model and the 24 entered variables to the women group, 9 of them were social-psychological variables, 2 of them were economic variables and 4 of them were environmental variables. In the next step, we calculated the specific vectors of all non-zero eigenvalues. Indeed, the specific vectors are among the loading corresponding to every index of the concerning factor which is named load factor. In the factor analysis, indices are connected together, and we use the indices with a correlation coefficient higher than 0.520 . Using the varimax rotation, the 62 variable were reduced to 23 for men and 24 for women; the four factors obtained can explain $86.15 \%$ of the 
Variance changes for men and $89.63 \%$ of the Variance changes for women.

This result indicates that the factor analysis and the studied factors in both of the groups are satisfactory. In this analysis, the percent of variance for the first factor, the second factor, the third factor and the fourth factor is: $86.09,5.46,2.26$ and 0.93 , respectively. And for the women's group, it is: $77.27,6.14,3.21$ and 3.01 , for the first, the second, the third and the fourth factors, respectively.

As identified variables in the research method, naming the four factors extracted from the analysis model was done for the social-psychological, economic, physical-structural, and environmental indices that are the same for both the men's and the women's group. Among social-psychological indices, the sense of need, the footwork of addicted people, and the sense of belonging to a place had the highest rate of significance, while the level of education, the sex and the age had the lowest significance rate. Also, the economic factor had two indices of loading including: the entrance cost to the park and the cost of utilization of park facilities. For the loading indices of the physical-structural factor, we can also say that the indices of finding a suitable place, the variation of access areas, and the consent of recreation facilities had the highest rate of meaningfulness, but the indices of waterfronts, and quality of the roads inside the park had the lowest significance rate. Finally, for the environmental factor, the variables of climate comfort, environmental health, freezing of parks and environment pollution had the first and the fourth priority rates, respectively (Table 5).

Final factors extracted from the factor analysis model

\begin{tabular}{|c|c|c|c|c|c|}
\hline Factor & $\begin{array}{l}\text { Used Indica- } \\
\text { tors }\end{array}$ & $\begin{array}{l}\text { Specific } \\
\text { value }\end{array}$ & $\begin{array}{c}\text { Cumula- } \\
\text { tive } \\
\text { variance- } \\
-(\%)\end{array}$ & Factor name & $\begin{array}{l}\text { Factor } \\
\text { Rating }\end{array}$ \\
\hline 1 & $\begin{array}{c}\mathrm{A}_{10}, \mathrm{~A}_{16}, \mathrm{~A}_{6} \\
\mathrm{~A}_{18 ،}, \mathrm{~A}_{13} \\
\mathrm{~A}_{14}, \mathrm{~A}_{1}, \mathrm{~A}_{2} ، \mathrm{~A}_{3}\end{array}$ & 24.692 & 40.380 & $\begin{array}{c}\text { Socio- } \\
\text { psychological }\end{array}$ & 1 \\
\hline 2 & $\mathrm{~B}_{6} \cdot \mathrm{B}_{7}$ & 7.628 & 12.211 & Economical & 3 \\
\hline 3 & $\begin{array}{c}\mathrm{C}_{1} \cdot \mathrm{C}_{3 ،} \mathrm{C}_{5^{6}} \\
\mathrm{C}_{10^{6}} \mathrm{C}_{7^{6}} \mathrm{C}_{14^{6}} \\
\mathrm{C}_{18^{6}} \mathrm{C}_{6}\end{array}$ & 15.309 & 24.484 & Physical -structure & 2 \\
\hline 4 & $\begin{array}{c}\mathrm{D}_{13^{6}} \mathrm{D}_{11^{6}} \mathrm{D}_{12^{6}} \\
\mathrm{D}_{8}\end{array}$ & 3.638 & 8.197 & Environmental & 4 \\
\hline
\end{tabular}

Source: Author (2018)

The first factor explains $39.380 \%$ of the variance for the men's group and $41.63 \%$ for the women's group, and it is introduced as the most important factor, because, by considering the nature of the loaded indices and with the 24.692 eigenvalue for men and 23.84 for the women's group, it has the highest impact among the four factors. And it is named as a socialpsychological factor and it indicates that the concerning indices of the factor are meaningfully correlated. The eigenvalue of the next factor is 7.365 for men and 6.368 for women which calculates and explains $12.652 \%$ of the variance for the men's group and $12.32 \%$ of the variance changes for the women's group. The factor has two loaded indices, thus, it is named as economic factor based on the loaded indices on the second factor. The eigenvalue of the third factor is 13.328 for men and 11.524 for women which calculates and interprets $25.147 \%$ of the variance changes for the men's group and $22.653 \%$ for the women's group. Therefore, 
based on the indices, we can name it physical-structural factor. The last loaded factor in the analysis model with 4 loaded indices and with a 6.365 eigenvalue explains about $8.542 \%$ of the men's group variance. With a 7.685 eigenvalue, it also explains $10.987 \%$ of the women's group variance and it enters the environmental indices. In total, the four above mentioned factors are loaded with 23 loaded indices for men and 24 for women which cover $85.272 \%$ of the variance variations of the men's group and $87.63 \%$ of the variance variations for the women behavior in urban parks and green spaces. Therefore, we can say that the socialpsychological indices, physical-structural indices, economic and environmental indices significantly impact the performance of social behavior settings in parks and green spaces of metropolises. According to the analysis results, economic factors are very important, and only with two loaded indices they are very capable and effective on the performance of social behavior setting at parks and green spaces of metropolises.

Using the method of the stepwise linear regression test, the obtained variables, based on the beta standard including social-psychological, economic, physical-structural, and environmental variables, had the highest shares in the variations of the named dependent variable (performance of social behavioral settings).

The results show that the predictor variables predict $87 \%(R 2=0.87)$ of the variance of the dependent variable. The coefficient of determination suggests that there have been other affecting variables on the performance rate of social behavioral settings that have not been studied. They have been excluded from the factor analysis model and, also, at the final step, the results of the unilateral variance analysis show that the regression and the linear relationship of the variables are meaningful (Table 6 , Table 7 ). Referring to the obtained calculation data of the estimation equation, the final model of multivariate regression is meaningful.

Table 6

Regression coefficients for explaining the relationships of four variables and the performance of social behavioral settings

\begin{tabular}{|c|c|c|c|c|c|c|}
\hline Step & $\begin{array}{c}\text { Variable } \\
\text { name }\end{array}$ & $\begin{array}{c}\text { Regres- } \\
\text { sion } \\
\text { coefficient }\end{array}$ & $\begin{array}{c}\text { Coefficient } \\
\text { of determi- } \\
\text { nation } \\
\mathbf{R}^{2}\end{array}$ & $\begin{array}{c}\text { Coeffi- } \\
\text { cient of } \\
\text { determi- } \\
\text { nation } \\
\text { justified }\end{array}$ & Value (f) & $\begin{array}{c}\text { Value } \\
\text { (p) }\end{array}$ \\
\hline 1 & $\begin{array}{c}\text { Socio- } \\
\text { psychologi- } \\
\text { cal }\end{array}$ & 0.874 & 0.798 & 0.605 & 174.74 & 0.000 \\
\hline 2 & Economical & 0.796 & 0.676 & 0.551 & 161.43 & 0.000 \\
\hline 3 & $\begin{array}{c}\text { Physical - } \\
\text { structure }\end{array}$ & 0.667 & 0.511 & 0.463 & 154.69 & 0.000 \\
\hline 4 & $\begin{array}{c}\text { Environ- } \\
\text { mental }\end{array}$ & 0.583 & 0.473 & 0.389 & 121.65 & 0.000 \\
\hline
\end{tabular}

Source: Author (2018)

The obtained results of the data analysis on the explanatory power of the concerning variables to the social-psychological, economic, physical-structural and environmental dimensions explain their effect on the performance rate of behavioral settings (Table 7). 
Coefficients of entered variables to the final regression equation for explaining the influencing factors on the performance of social behavioral settings

\begin{tabular}{|c|c|c|c|c|c|}
\hline \multirow{2}{*}{ Predicted variables } & \multicolumn{2}{|c|}{$\begin{array}{l}\text { Not Standardized } \\
\text { coefficients }\end{array}$} & \multirow{2}{*}{$\begin{array}{c}\begin{array}{c}\text { Standar- } \\
\text { dized coeffi- } \\
\text { cients }\end{array} \\
(\beta)\end{array}$} & \multirow{2}{*}{$\begin{array}{c}\text { Calcula- } \\
\text { ted } \\
t\end{array}$} & \multirow{2}{*}{$\begin{array}{c}\text { Value } \\
\text { (p) }\end{array}$} \\
\hline & $\begin{array}{c}\text { Stand- } \\
\text { ard error }\end{array}$ & $\begin{array}{l}\text { Login } \\
\text { factor }\end{array}$ & & & \\
\hline Constant number (Intercept) & 3.01 & 32.8 & - & 8.65 & 0.000 \\
\hline Socio-psychological & 0.531 & 8.65 & 0.669 & 7.80 & 0.000 \\
\hline Physical-structure & 0.663 & 6.32 & 0.573 & 5.64 & 0.000 \\
\hline Economical & 0.799 & 3.43 & 0.499 & 3.65 & 0.000 \\
\hline Environmental & 0.698 & 4.51 & 0.389 & 3.83 & 0.000 \\
\hline
\end{tabular}

Source: Author (2018)

Table 8

Independent $t$ test results in relation with the performance of parks and green spaces as women and men behavior setting

\begin{tabular}{|c|c|c|c|c|c|c|c|}
\hline & \multicolumn{2}{|c|}{$\begin{array}{c}\text { Leneva test for } \\
\text { Equal of Vari- } \\
\text { ances }\end{array}$} & \multicolumn{6}{|c|}{ t-test for Equal of Mean } \\
\cline { 2 - 7 } & $\mathbf{f}$ & sig & $\mathbf{t}$ & df & $\begin{array}{c}\text { Sig (2- } \\
\text { tailed) }\end{array}$ & $\begin{array}{c}\text { Mean dif- } \\
\text { ference }\end{array}$ & $\begin{array}{c}\text { Std Error } \\
\text { difference }\end{array}$ \\
\hline $\begin{array}{c}\text { Equal Var- } \\
\text { iances } \\
\text { assumed }\end{array}$ & 8.652 & 0.003 & 0.875 & 24 & 0.257 & -48.0000 & 0.58724 \\
$\begin{array}{c}\text { Equal Var- } \\
\text { iances not } \\
\text { assumed }\end{array}$ & & 0.745 & & 0.262 & -48.0000 & 0.56573 \\
\hline
\end{tabular}

Source: Author (2018)

The stepwise results (Table 8) entered to the final regression model in terms of the importance of the concerning variables to the four research hypotheses showed that the concerning variables to the social-psychological factors, physical-structural factors, economic and environmental factors had the greatest correlation and effect on the performance of behavioral settings at parks and green spaces of metropolises.

At the end, the independent $t$ test was used for surveying the related variables differences of citizen's social behavior setting in the use of parks and green spaces. The results showed that there are significant differences between sex and behavior setting in parks and green spaces at a 0.262 level with 0.745 amounts.

\section{Discussion}

As discussed on the current research, urban spaces, especially metropolis spaces, are too overcrowded and they are confronting with polluted air, noise pollution and social malformations, while often becoming boring for the citizens. Thus, the urban residents choose 
urban parks and urban green areas as resorts and revitalization places for spiritual and mental peace. As mentioned before, the people and the environment have mutual effects for their interactions, therefore parks and urban green areas must be designed so that to provide peace and serenity for the citizens more than ever.

The objective of this paper was to analyze the influencing factors on the performance of social behavioral settings at parks and green spaces of Tabriz metropolis. The descriptive results showed that men's and women's visits to parks and green spaces are approximately equal. In terms of education, the majority of subjects had a bachelor's degree. Also, the mean age group of 30 to 40 included the most motivated people who went three times a week to the parks for peace and revitalization.

The results of the factor analysis showed that the social-psychological factor had the greatest percentage in explaining the performance of social behavioral settings at parks and urban green spaces. Then, the physical-structural factor, the economic factor, and the environmental factor were the next priorities, respectively. The obtained research results are compatible with those of Lee and Park (2013) for the relative importance of the four factors. In this regard, we can say that citizen social and psychological features and men's and women's psychological features must be focused in the designing process and park management, by considering this to improve the performance of such spaces. For example, this is important in the case of considering the official religion of Iran that is Shi Islam and the emphasis on no mixing men and women because of women's mandatory hijab in public places. Taking into account the psychological features of men and women will improve the performance level of urban parks and green spaces as citizens' behavior setting. The results of the research analysis and the stepwise linear regression test showed that the concerning variables of the social psychological factor had the greatest rate of correlation with the dependent variable. Finally, the results of the independent t-test showed that there are significant differences between the women's and men's understanding of urban parks and green spaces.

The physical-structural, economic and environmental variables have the next priority by following the results of the factor analysis model. These findings are compatible with those of Parker and Nilon (2008), Maas et al. (2009). Accordingly, we can say that parks are places where people with different cultural, social and economic features are gathered, so that every citizen has different needs and requirements depending on his or her personal traits while they interact with society and environmental spaces differently.

However, despite the existing differences of citizens' needs and requirements, there is a consensus and unity on which we can focus in the planning process in order to satisfy the majority of the citizens and to increase the success rate of urban plans and projects. Parks and urban green spaces are social behavioral settings for the residents which should be considered by the urban managers. We can increase the attraction of parks by focusing more on the sociocultural and psychological traits of people such as their beliefs, their sense of place, their identity, and on their anthropological features such as age, gender, level of education, family status, financial status, economic situation, the amount of income, the variations of income resources; but also on environmental and physical aesthetic factors, such as furniture arrangements in the parks, proper utilization of environmental elements, quality of vegetation and green space. Moreover, the research findings of Rosol (2010) on the involvement of citizens' needs and requirements in the designing process of parks and urban green spaces have been limelight for planners and managers. Also, the citizens' participation is increased at the same rate in the maintenance and protection process of such spaces. Furthermore, according to the results of this survey, the needs and behavior patterns of space users must be considered.

Improving the environmental quality of urban public spaces such as urban parks and green 
spaces is not a mono-dimensional issue, so all economic, social, environmental, and psychological components should be considered. So we can conclude that improving the environmental quality effect of its elements on spaces and behavior patterns in urban parks is not only conceptual and of technical quality, but it is associated with qualitative concepts like the physical environment quality, and the verity of social spaces and interactions through social activities, spatial dependence and urban environment quality.

Effective elements on the environmental quality of public places such as urban parks have a bilateral relation with their users' behavior patterns. On the other hand, behavior settings are more determinist than the physical environment patterns. As a result, the compatibility of behavior and environment is to present the user's merit in spaces and their imparted features. Analyzing urban parks as behavior setting gives rich recognition of the human behavior. Such analysis provides information about individual and group differences and about behavior patterns that can make designers free from the stereotype of people and their activities. So, planning and urban designing must not clash directly with public places presents and urban park users' behavior patterns or want to change or correct behaviors. But it must try to improve urban parks quality by using the existing tools and the effective techniques in order to design urban park spaces in a way that provide the necessary conditions for an increased environmental quality of parks in the future.

\section{Conclusions}

Regarding the research findings, the following practical suggestions are important for the performance improvement of behavioral settings at parks and green spaces of metropolises.

Sociocultural, economic, anthropological needs of the residents must be comprehensively and completely analyzed in the designing and execution process of parks and green spaces of metropolises, including serious consideration to the psychological features of women and men in the context of their religious beliefs.

Environmental elements such as climate, humidity, gradient, rain, light and radiation, and the reflection of sunlight should be considered in the design and implementation of the processes of parks and green spaces of the city, so that these components can be used to increase the exhilaration of citizens in the used parks.

Technical and physical rules and regulations must be observed in the designing process of parks and urban green spaces, including: locating, access areas, furniture arrangement, visual quality, environmental health and so forth. Therefore, we must try to promote urban park design standards in the metropolitan Tabriz. Some areas must be provided for the citizens' active and constructive participation before, during and after the execution of designs and we must continually attract citizens and motivate them for their physical, financial and intellectual participation within urban areas. Generally, a systemic approach must be adopted for the immersive and horizontal prevention of manner-oriented conflicts in the designing process of parks and green spaces of metropolises.

\section{References}

BALRAM S., DRAGIĆEVIĆ S. (2005), Attitudes Toward Urban Green Space: Integrating Questionnaire Survey and Collaborative GIS Techniques to Improve Attitude Measurements, Landscape and Urban Planning 71 (2-4), 147-162.

BARANOWSKI T., PERRY C. L., PARCEL G. S. (2002), How individuals, environments, and health behavior interact, in: Glanz K., Rimer B. K., Lewis F. M. (eds.), Health Behavior and Health Education: Theory, Research, and Practice 3rd edition, Jossey-Bass., San Francisco, pp. $165-184$. 
BARBOSA O., TRATALOS J. A., ARMSWORTH P. R., DAVIES R. G., FULLER R. A., JOHNSON P., GASTON K. J. (2007), Who benefits from access to green space? A case study from Sheffield, UK, Landscape and Urban Planning 83 (2-3), 187-195.

BARKER R. G. (1968), Ecological Psychology. Concepts and Methods for Studying the Environment of Human Behavior, Stanford University Press, Stanford.

BARTHEL S., PARKER J., ERNSTSON H. (2015), Food and green space in cities: A resilience lens on gardens and urban environmental movements, Urban Studies 52 (7), 1321 1338.

BARTLETT J. E. II, KOTRLIK J. W., HIGGINS C. C. (2001), Organizational Research: Determining Appropriate Sample Size in Survey Research, Information Technology, Learning, and Performance Journal 19 (1), 43-50.

BERTRAM C., REHDANZ K. (2015), The role of urban green space for human wellbeing, Ecological Economics 120, 139-152.

BLANCHARD A. (2004), Virtual behavior settings: An application of behavior setting theories to virtual communities, Journal of Computer $\square$ Mediated Communication 9 (2), 10-22.

BORER M. I. (2006), Important places and their public faces: Understanding Fenway Park as a public symbol, The Journal of Popular Culture 39 (2), 205-224.

BRESNAHAN M., LEE S. Y., SMITH S. W., SHEARMAN S., NEBASHI R., PARK C. Y., YOO J. (2007), A theory of planned behavior study of college students' intention to register as organ donors in Japan, Korea, and the United States, Health Communication 21 (3), 201-211.

CARRUS G., SCOPELLITI M., LAFORTEZZA R., COLANGELO G., FERRINI F., SALBITANO F., AGRIMI M., PORTOGHESI L., SEMENZATO P., SANESI G. (2015), Go greener, feel better? The positive effects of biodiversity on the well-being of individuals visiting urban and peri-urban green areas, Landscape and Urban Planning 134, 221-228.

CASPERSEN O. H., KONIJNENDIJK C. C., OLAFSSON A. S. (2006), Green space planning and land use: An assessment of urban regional and green structure planning in Greater Copenhagen, Geografisk Tidsskrift-Danish Journal of Geography 106 (2), 7-20.

CHEN B., ADIMO O. A., BAO Z. (2009), Assessment of aesthetic quality and multiple functions of urban green space from the users' perspective: The case of Hangzhou Flower Garden, China, Landscape and Urban Planning 93 (1), 76-82.

CHIESURA A. (2004), The role of urban parks for the sustainable city, Landscape and Urban Planning 68 (1), 129-138.

COLDING J., BARTHEL S. (2013), The potential of 'Urban Green Commons' in the resilience building of cities, Ecological Economics 86, 156-166.

COOMBES E., JONES A. P., HILLSDON M. (2010), The relationship of physical activity and overweight to objectively measured green space accessibility and use, Social Science Medicine 70 (6), 816-822.

COSCO N. G., MOORE R. C., ISLAM M. Z. (2010), Behavior mapping: a method for linking preschool physical activity and outdoor design, Medicine Science in Sports Exercise 42 (3), 513-519.

COUTTS C., HORNER M., CHAPIN T. (2010), Using geographical information system to model the effects of green space accessibility on mortality in Florida, Geocarto International 25 (6), 471-484.

DE SOUSA C. A. (2003), Turning brownfields into green space in the City of Toronto, Landscape and Urban Planning 62 (4), 181-198.

DICLEMENTE R. J., SALAZAR L. F., CROSBY R. A. (2013), Health behavior theory for public health: Principles, Foundations, and Applications, Jones \& Bartlett Learning, Burlington.

DOBBS C., KENDAL D., NITSCHKE C. R. (2014), Multiple ecosystem services and disservices of the urban forest establishing their connections with landscape structure and sociodemographics, Ecological Indicators 43, 44-55.

DOUGLAS O., LENNON M., SCOTT M. (2017), Green space benefits for health and well-being: A life-course approach for urban planning, design and management, Cities 66, 5362. 
DU Y., GAO B., ZHOU H., JU X., HAO H., YIN S. (2013), Health risk assessment of heavy metals in road dusts in urban parks of Beijing, China, Procedia Environmental Sciences 18, 299-309.

FILIPAN K., BOES M., DE COENSEL B., LAVANDIER C., DELAITRE P., DOMITROVIĆ H., BOTTELDOOREN D. (2017), The personal viewpoint on the meaning of tranquility affects the appraisal of the urban park soundscape, Applied Sciences-Basel 7 (1), 91.

GALEA S., FREUDENBERG N., VLAHOV D. (2005), Cities and population health, Social Science Medicine 60 (5), 1017-1033.

GUÉGUEN N., STEFAN J. (2016), "Green Altruism": Short Immersion in Natural Green Environments and Helping Behavior, Environment and Behavior 48 (2), 324-342.

HARNIK P. (2006), The excellent city park system: What makes it great and how to get there, in: Platt R. H., The Human Metropolis: People and Nature in the 21st-Century City, University of Massachusetts Press, Amherst, pp. 47-60.

HELMS J. E., HENZE K. T., SASS T. L., MIFSUD V. A. (2006), Treating Cronbach's Alpha Reliability Coefficients as Data in Counseling Research, The Counseling Psychologist 34 (5), 630-660.

HEYNEN N., PERKINS H. A., ROY P. (2006), The political ecology of uneven urban green space: The impact of political economy on race and ethnicity in producing environmental inequality in Milwaukee, Urban Affairs Review 42 (1), 3-25.

HONOLD J., LAKES T., BEYER R., VAN DER MEER E. (2016), Restoration in urban spaces: Nature views from home, greenways, and public parks, Environment and Behavior 48 (6), 796-825.

IGNATIEVA M., STEWART G. H., MEURK C. (2011), Planning and design of ecological networks in urban areas, Landscape and Ecological Engineering 7 (1), 17-25.

JENNINGS V., LARSON L., YUN J. (2016), Advancing sustainability through urban green space: cultural ecosystem services, equity, and social determinants of health, International Journal of Environmental Research and Public Health 13 (2), 196.

JOKIMÄKI J. (1999), Occurrence of breeding bird species in urban parks: effects of park structure and broad-scale variables, Urban Ecosystems 3 (1), 21-34.

KONG F., YIN H., NAKAGOSHI N., ZONG Y. (2010), Urban green space network development for biodiversity conservation: Identification based on graph theory and gravity modeling, Landscape and Urban Planning 95 (1-2), 16-27.

LACHOWYCZ K., JONES A. P. (2013), Towards a better understanding of the relationship between greenspace and health: development of a theoretical framework, Landscape and Urban Planning 118, 62-69.

LEE H. J., PARK S.-Y. (2013), Environmental orientation in going green: A qualitative approach to consumer psychology and sociocultural factors of green consumption, Journal of Global Scholars of Marketing Science 23 (3), 245-262.

LI F., WANG R. (2004), Research advance in ecosystem service of urban green space, Ying Yong Sheng tai xue bao = The Journal of Applied Ecology 15 (3), 527-531.

LIU C.-W. (2012), Challenges of Tourism upon the Local Community: Behavior settings in an old street in Tamsui, Taiwan, Procedia - Social and Behavioral Sciences 68, 305-318.

LOUKAITOU-SIDERIS A. (1995), Urban form and social context: cultural differentiation in the uses of urban parks, Journal of Planning Education and Research 14 (2), 89-102.

MAAS J., SPREEUWENBERG P., VAN WINSUM-WESTRA M., VERHEIJ R. A., VRIES S., GROENEWEGEN P. P. (2009), Is green space in the living environment associated with people's feelings of social safety?, Environment and Planning A: Economy and Space 41 (7), 1763-1777.

MALHEIROS J. M., VALA F. (2004), Immigration and city change: the Lisbon metropolis at the turn of the twentieth century, Journal of Ethnic and Migration Studies 30 (6), 1065-1086. New York.

MCDONALD R. P. (2014), Factor analysis and related methods, Psychology Press, 
MIDDEL A., CHHETRI N., QUAY R. (2015), Urban forestry and cool roofs: Assessment of heat mitigation strategies in Phoenix residential neighborhoods, Urban Forestry \& Urban Greening 14 (1), 178-186.

NGESAN M. R., KARIM H. A., ZUBIR S. S. S. (2018), Relationship between Nighttime Leisure Behaviour and Urban Park Setting in Shah Alam, Asian Journal of Behavioural Studies 3 (9), 173-181.

NOAR S. M., CHABOT M., ZIMMERMAN R. S. (2008), Applying health behavior theory to multiple behavior change: considerations and approaches, Preventive Medicine 46 (3), 275280.

NORDH H., ALALOUCH C., HARTIG T. (2011), Assessing restorative components of small urban parks using conjoint methodology, Urban Forestry \& Urban Greening 10 (2), 95103.

PARKER T. S., NILON C. H. (2008), Gray squirrel density, habitat suitability, and behavior in urban parks, Urban Ecosystems 11 (3), 243-255.

PEARSON E. S. (2012), Goal setting as a health behavior change strategy in overweight and obese adults: A systematic literature review examining intervention components, Patient Education and Counseling 87 (1), 32-42.

POTESTIO M. L., PATEL A. B., POWELL C. D., MCNEIL D. A., JACOBSON R. D., MCLAREN L. (2009), Is there an association between spatial access to parks/green space and childhood overweight/obesity in Calgary, Canada?, International Journal of Behavioral Nutrition and Physical Activity 6, 77.

ROSOL M. (2010), Public Participation in Post- Fordist Urban Green Space Governance: The Case of Community Gardens in Berlin, International Journal of Urban and Regional Research 34 (3), 548-563.

RUPPRECHT C. D. D., BYRNE J. A., UEDA H., LO A. Y. (2015), 'It's real, not fake like a park': Residents' perception and use of informal urban green-space in Brisbane, Australia and Sapporo, Japan, Landscape and Urban Planning 143, 205-218.

RUTT R. L., GULSRUD N. M. (2016), Green justice in the city: A new agenda for urban green space research in Europe, Urban Forestry \& Urban Greening 19, 123-127.

SALDIVAR-TANAKA L., KRASNY M. E. (2004), Culturing community development, neighborhood open space, and civic agriculture: The case of Latino community gardens in New York City, Agriculture and Human Values 21 (4), 399-412.

SANCHEZ G. M. E., VAN RENTERGHEM T., SUN K., DE COENSEL B., BOTTELDOOREN D. (2017), Using Virtual Reality for assessing the role of noise in the audiovisual design of an urban public space, Landscape and Úrban Planning 167, 98-107.

SANDSTRÖM U. G., ANGELSTAM P., MIKUSIŃSKI G. (2006), Ecological diversity of birds in relation to the structure of urban green space, Landscape and Urban Planning 77 (1-2), 39-53.

SHIN Y., KIM M. S., CHOI J. N., KIM M., OH W.-K. (2017), Does leader-follower regulatory fit matter? The role of regulatory fit in followers' organizational citizenship behavior, Journal of Management 43 (4), 1211-1233.

SISTER C., WOLCH J., WILSON J. (2010), Got green? Addressing environmental justice in park provision, GeoJournal 75 (3), 229-248.

STEFANSDOTTIR H. (2018), The role of urban atmosphere for non-work activity locations, Journal of Urban Design 23 (3), 319-335.

TAPPERT S., KLÖTI T., DRILLING M. (2018), Contested urban green spaces in the compact city: The (re-)negotiation of urban gardening in Swiss cities, Landscape and Urban Planning 170, 69-78.

THOMPSON C. W. (2002), Urban open space in the 21st century, Landscape and Urban Planning 60 (2), 59-72.

THOMPSON C. W., ROE J., ASPINALL P., MITCHELL R., CLOW A., MILLER D. (2012), More green space is linked to less stress in deprived communities: Evidence from salivary cortisol patterns, Landscape and Urban Planning 105 (3), 221-229. 
TOBIAS S., CARLSON J. E. (1969), Brief report: Bartlett's test of sphericity and chance findings in factor analysis, Multivariate Behavioral Research 4 (3), 375-377.

TOUTAKHANE A. M., MOFAREH M. (2016), Investigation and evaluation of spatial patterns in Tabriz parks using landscape metrics, Journal of Urban and Environmental Engineering 10 (2), 263-269.

VEITCH J., BALL K., CRAWFORD D., ABBOTT G. R., SALMON, J. (2012), Park improvements and park activity: a natural experiment, American Journal of Preventive Medicine 42 (6), 616-619.

WENDEL H. E. W., ZARGER R. K., MIHELCIC J. R. (2012), Accessibility and usability: Green space preferences, perceptions, and barriers in a rapidly urbanizing city in Latin America, Landscape and Urban Planning 107 (3), 272-282.

WHITBURN J., LINKLATER W. L., MILFONT T. L. (2018), Exposure to urban nature and tree planting are related to pro-environmental behavior via connection to nature, the use of nature for psychological restoration, and environmental attitudes, Environment and Behavior, OnlineFirst.

WILLIAMS B., ONSMAN A., BROWN T. (2010), Exploratory factor analysis: A five-step guide for novices, Journal of Emergency Primary Health Care 8 (3), 1-13.

WOLCH J. R., BYRNE J., NEWELL J. P. (2014), Urban green space, public health, and environmental justice: The challenge of making cities 'just green enough', Landscape and Urban Planning 125, 234-244.

XU X., SUN S., LIU W., GARCÍA E. H., HE L., CAI Q., XU S., WANG J., ZHU J. (2017), The cooling and energy saving effect of landscape design parameters of urban park in summer: A case of Beijing, China, Energy and Buildings 149, 91-100.

YOU H. (2016), Characterizing the inequalities in urban public green space provision in Shenzhen, China, Habitat International 56, 176-180.

ZUBE E. H. (1995), Greenways and the US national park system, Landscape and Urban Planning 33 (1-3), 17-25.

Initial submission: 05.07.2018

Revised submission: 30.10 .2018

Final acceptance: 19.11.2018

Correspondence: Department of Architecture, Faculty of Art and Architecture, University of Bonab, Velayat Highway, 5551761167, Bonab, Iran.

Email: a.majnoony@bonabu.ac.ir 
